Chemical analyses of suspended and dissolved heavy metals are given in table 1 . Appreciable heavy metal anomalies are found in sea water adjacent to the main ore body. The impression is gained that a large volume of water is contained locally in the fjord system, since the observed concentrations are markedly higher than those found in Arctic Ocean water. According to preliminary calculations the containment period for sea water in this fjord area is less than one year. It can be mentioned that no similar anomalies in heavy metal content have been found in the fish from the area, whereas the seaweed and mussels in the immediate vicinity of the mineralisation contain abnormally high heavy metal concentrations.

\title{
References
}

Vandkvalitetsinstituttet 1972: Recipientundersøgelse for Grønlands tekniske Organisation. Undersøgelsen af Qaumarujuk Fjord, Agfardlikavsâ. August 1972. København: Vandkvalitetsinstituttet, ATV.

Geological map of Greenland 1:100 000 Mârmorilik 71 V.2 S. København: Grønlands Geologiske Undersøgelse.

\section{INVESTIGATIONS ON THE NAGSSUGTOQIDIAN BOUNDARY IN THE HOLSTEINSBORG DISTRICT, CENTRAL WEST GREENLAND}

\author{
Juan Watterson
}

This was the second season of a cooperative effort by GGU and the University of Liverpool which is aimed at determining the displacements and history of the boundary region. In addition to the writer, the following geologists participated in the mapping work: J. Grocott and D. Nash (University of Liverpool), C. Talbot (University of Dundee), and J. Diggens (Kingston Polytechnic). In addition G. Beckman and C. Morgan (Imperial College, London) carried out a palaeomagnetic sampling programme, and B. Scott (University of Edinburgh) a sampling programme on the kimberlitic dyke suite.

Transport in the field was provided by the motor-boat 'Kimberlit' and two Zodiac inflatables, with some helicopter transport provided by Diapros Canada Ltd. which is gratefully acknowledged.

The succession of events previously reported (Bridgwater et al., 1973a) requires only minor modifications but previous ideas about the relative importance of pre- and post-dyke deformations have been substantially altered. 


\section{Relative age of the main Nagssugtoqidian deformation}

Two of the phenomena which define the boundary are:

(1) a strong tectonite fabric within the Nagssugtoqidian, resulting in a persistent ENE strike direction which is absent from pre-Nagssugtoqidian rocks south of the boundary, and

(2) a change in strike direction of the Kangâmiut dyke swarm from NNE south of the boundary to ENE within the Nagssugtoqidian.

It was originally believed that post-dyke deformation was responsible both for the imposition of the tectonite fabrics and the characteristic NNE Nagssugtoqidian trend, and for the change in attitude of the dykes (Noe-Nygaard \& Ramberg, 1961). This belief was supported by work on the boundary in the plateau region between the Sukkertoppen Iskappe and Søndre Strømfjord air-base (Escher et al., 1970) although some overlap between deformation and dyke emplacement was evident 15-20 km north of the boundary in Søndre Strømfjord. Subsequent work in the coastal region (Bridgwater et al., 1973a) provided clear evidence of pre-dyke deformation (Nag. 1) with steep ENE tectonite fabrics resulting from dextral displacement along an E-W vertical shear zone several kilometres in width. Kangâmiut dykes within this shear zone have ENE strike directions, i.e. parallel to the country rock fabric, but have undergone little or no deformation; as the dykes cannot have been tectonically reoriented their ENE strike in this shear zone is clearly an original feature and controlled by the pre-dyke tectonic fabric of the country rocks. Within the amphibolite facies rocks of the shear zone dykes also show a pinch and swell form, which although reminiscent of boudinage is not the result of tectonic deformation. This conclusion is substantiated by original undeformed igneous textures within pinch and swell dykes which show the pinch and swell form to have existed before appreciable crystallisation of the intrusive liquid. The local ductile deformation of the amphibolite facies country rocks which was necessary to accomodate the pinch and swell dyke forms, provides conclusive evidence of the high temperatures of the country rocks at the time of dyke emplacement. It has been argued previously (Bridgwater et al., 1973b) that no significant temperature difference existed between granulite and amphibolite facies areas at the time of dyke emplacement, and the normal parallel sided dyke forms in granulite facies country rocks are now ascribed to the less ductile nature of the granulite facies compared with amphibolite facies rocks at the same temperature.

Although a pre-dyke deformation was recognised earlier, until this year it was still believed to be of little regional importance relative to the post-dyke deformation which was still regarded as the main Nagssugtoqidian deformation (Bridgwater et al. 1973b). Work this year between Ikertoq and Amerdloq fjords has shown that the post-dyke deformation is relatively slight and certainly insufficient 
to account for the present ENE strike of the dykes as a result of tectonic reorientation from an original NNE direction. It now appears that

(1) the main Nagssugtoqidian deformation, and the characteristic ENE strike, are both pre-dyke in age, and

(2) that the regional change in direction of the dyke swarm is, to a large extent, an original feature. Only within $10-15 \mathrm{~km}$ of the boundary in the inland plateau region have dykes been tectonically reoriented to any considerable extent.

\section{Ikertoq zone}

The northernmost limit of Kangâmiut dykes in the coastal region has now definitely been established on the north-west coast of Sarfánguaqland, coinciding with the northern boundary of what Noe-Nygaard \& Ramberg (1961) defined as the Ikertoq complex, here referred to as the Ikertoq zone. In the coastal region the Ikertoq zone is a $c .40 \mathrm{~km}$ wide strip forming the southern edge of the Nagssugtoqidian and consisting of amphibolite facies gneisses bounded to both north and south by granulite facies rocks. In addition to defining the northern limit of the Kangâmiut dykes, and of the amphibolite facies, the northern edge of the Ikertoq zone is a lithological boundary to the north of which supracrustal and granitic rocks replace more anonymous banded gneisses. The supracrustal rocks include marbles, calc-silicates, quartz-pyrite rocks, garnet-sillimanite schists, and siliceous horizons thought to represent acid volcanics. Pseudotachylite veins occur throughout the Ikertoq zone but are especially concentrated on the northern margin which was the locus of intense brittle deformation, mostly post-dyke in age. The Ikertoq zone in general and its northern margin in particular, is interpreted as a palaeoseismic zone on the basis of the pseudotachylite occurrences. A marked decrease in intensity of ductile deformation has been established north from the Ikertoq zone and the northern boundary of the zone is therefore marked by changes in five different characters:

(1) metamorphic facies; (2) lithology; (3) intensity of ductile deformation; (4) dyke distribution; (5) brittle deformation and pseudotachylites. Further work is planned on this critical boundary.

The nature and amount of the displacements represented by the ductile deformation in the Ikertoq zone have not yet been firmly established but are believed to represent an ENE-striking zone of mainly transcurrent, dextral, ductile shear movement. The view of the Nagssugtoqidian as a single well-defined mobile belt is becoming increasingly unsatisfactory. Although it is not yet possible to put forward a convincing new generalisation, any new proposal must take into account the existence of several large-scale zones of simple shear with dominantly transcurrent displacements, which are not confined to the 'classical' Nagssugtoqidian belt but which occur over probably $450 \mathrm{~km}$ of the coast of West Greenland. 


\section{Supracrustals of Nagssugtoqidian age}

The small outcrop of supracrustal rocks on the plateau $8 \mathrm{~km}$ north of the Sukkertoppen Iskappe was also mapped (Diggens \& Talbot, this report). The conclusion that these rocks form a klippe and have been transported in a southerly direction is in accordance with the ductile overthrust displacements in the underlying gneisses (Bridgwater et al., 1973b).

\section{Palaeomagnetic work}

The palaeomagnetic sampling programme included both Kangâmiut dykes and country rock gneisses, in addition to some kimberlites, and it is hoped that this work, in conjunction with a radiometric study of the palaeomagnetic samples will provide information on the thermal history of the region. It is intended to continue this programme in 1974.

\section{Kimberlite suite}

Sampling of numerous small instrusions of this suite was carried out to provide material for a detailed petrological study to complement a diamond prospecting programme. Kimberlites sensu stricto have been found only in the rocks bordering the Ikertoq zone which itself contains numerous small intrusions of mica peridotite.

\section{Succession of events}

The following is a revised version of that part of the previously published succession of events (Bridgwater et al., 1973a) which requires modification.

Later

Nagssugtoqidian deformation

(Nag. 2)
Ductile overthrusting from NNW in discrete zones, some migmatisation of Kangâmiut dykes.

Southerly directed thrusting of supracrustal sequence.

Emplacement of Kangâmiut dykes. In areas not affected by Nag. 1 striking NNE, elsewhere parallel to ENE Nag. 1 fabric. Synkinematic features evident locally.

Emplacement of E-W basic dykes, sparse.

Brittle deformation parallel to Nag. 1 fabric with production of pseudotachylite.

Pegmatites

$\left.\begin{array}{l}\begin{array}{l}\text { Main } \\ \text { Nagssugtoqidian } \\ \text { deformation } \\ \text { (Nag. 1) }\end{array}\end{array}\right\} \begin{aligned} & \text { Ductile simple shear strain. Imposition of intense tectonite fabrics on } \\ & \text { previously isotopic rocks. Displacements mainly transcurrent dextral. }\end{aligned}$

Regional high-grade metamorphism c. $2800 \mathrm{~m} . \mathrm{y}$. 


\title{
References
}

Bridgwater, D., Escher, A., Nash, D. F. \& Watterson, J. 1973a: Investigations on the Nagssugtoqidian boundary between Holsteinsborg and Kangâmiut, central West Greenland. Rapp. Grønlands geol. Unders. 55, 22-25.

Bridgwater, D., Escher, A. \& Watterson, J. 1973b: Tectonic displacements and thermal activity in two contrasting Proterozoic mobile belts from Greenland. Phil. Trans. R. Soc. Lond. A, 273, 513-533.

Escher, A., Escher, J. \& Watterson, J. 1970: The Nagssugtoqidian boundary and the deformation of the Kangâmiut dyke swarm in the Søndre Strømfjord area. Rapp. Grønlands geol. Unders. 28, 21-23.

Noe-Nygaard, A. \& Ramberg, H. 1961: Geological reconnaissance map of the country between latitudes $69^{\circ} \mathrm{N}$ and $63^{\circ} 45 \mathrm{~N}$, West Greenland. Map Grønlands geol. Unders. 1 (also Meddr Grønland 123,5) 2 sheets, 9 pp.

Jane Herdman Laboratories of Geology, University of Liverpool, Brownlow Street, Liverpool L69 $3 B X$, $U . K$.

\section{NAGSSUGTOQIDIAN SUPRACRUSTAL METAVOLCANIC ROCKS OF SARFARTOPP NUNÂ, SØNDRE STRØMFJORD, CENTRAL WEST GREENLAND}

\author{
John Diggens and Christopher Talbot
}

The area discussed here is situated $8 \mathrm{~km}$ north of the Sukkertoppen Iskappe and $10 \mathrm{~km}$ east of S $\emptyset$ ndre Str $\varnothing \mathrm{mfjord}$ at $66^{\circ} 27^{\prime} \mathrm{N}, 51^{\circ} 50^{\prime} \mathrm{W}$. The work was undertaken during August as part of the programme led by Dr. J. Watterson (see this report).

The outcrop of supracrustal metavolcanic rocks is less than $15 \mathrm{~km}^{2}$ in extent. They consist of greenschist to low amphibolite facies schists disposed in an eastwest trending synformal basin and overlying Archaean gneisses modified by Nagssugtoquidian shearing. The south-eastern margin of the Nagssugtoqidian mobile belt is $15 \mathrm{~km}$ east of this area (Bridgwater et al., 1973).

\section{The succession}

The supracrustal succession of Sarfartûp nunâ consists of layered sequences of actinolite schist, actinolite-chlorite schist, tremolite-calcite schist, chlorite-muscovite phyllite, and sills and dykes of garnet amphibolite. At or near the base of the succession, there is a large metamorphosed ultrabasic sill up to $200 \mathrm{~m}$ thick. 